\title{
PENDIDIKAN AGAMA KRISTEN YANG ATIPATIF DAN HOAKS DI ERA DIGITAL: TINJAUAN LITERATUR REVIEW
}

\author{
Fredik Melkias Boiliu \\ Universitas Kristen Indonesia, J1.Diponegoro, No. 84-86 \\ Jakarta Pusat 10430 boiliufredik@gmail.com
}

Diterima 28 Februari 2020, disetujui 30 April 2020, diterbitkan 30 April 2020

Pengutipan: Boiliu, F.M. (2020). Pendidikan Agama Kristen Yang Atipatif Dan Hoaks Di Era Digital: Tinjauan Literatur Review. Gema Wiralodra, Vol 11, No 1, Hal 154-169, April 2020

\begin{abstract}
ABSTRAK
Artikel ini akan membahas tentang pendidikan agama Kristen yang antipatif terhadap hoaks di digital. Hoaks yang terus berkembang dan beredar dengan begitu cepat di media sosial bagaikan virus yang merajalelah maka penulis mamasukan pendidikan agama Kristen untuk mengantisipasi hoaks yang sedang terjadi dan yang akan terjadi melalui pengajaran pendidikan agama Kristen di lingkungan keluarga, gereja dan sekolah. Dalam hal ini, keluarga, gereja dan sekolah memiliki peran penting untuk membantu pemerintah memutuskan mata rantai hoaks. Pengajaran pendidikan agama Kristen di keluarga melalui peran orang tua sebagai pengajar, pendidik dan pendamping pada anak, Pendidikan agama Kristen di gereja melalaui peran gereja mengajarkan kepada jemaat bahwa menciptakan dan menyebarkan hoaks adalah melakukan dosa dan peran pendidikan agama Kristen di sekolah melalui peran guru dalam menjar, membimbing dan mengarahkan siswa di dalam penggunaan media sosial. Peran pendidikan agama bisa di terapkan pada agama lain selain agama Kristen. Pada penulisan ini, penulis menggunakan metode kajian literatur dan riset pustaka yakni menggunakan ide-ide tertulis sebagai sumber penekanan pada interpretasi dan analisis makna konsep pemikiran dalam bentuk ekspresi baik ide empiris dan ide-ide rasional.
\end{abstract}

Kata Kunci: Era Digital, Hoaks, Pendidikan Agama Kristen

\section{ABSTRACT}

This article will discuss Christian religious education which is antipative to hoaks in digital. Hoaks that continue to grow and circulate so quickly on social media like a rampant virus, the author enters Christian religious education to anticipate the hoaks that are happening and will happen through teaching Christian religious education in the family, church and school environment. In this case, family, church and school have an important role to help the government break the chain of hoaks. Teaching Christian religious education in the family through the role of parents as teachers, educators and assistants to children, Christian religious education in the church through the role of the church teaches the congregation that creating and spreading hoaks is committing sin and the role of Christian religious education in schools through the role of teachers in running, guiding and directing students in the use of social media. The role of religious education can be applied to other religions besides Christianity. At this writing, the author uses the method of literature review and literature research that uses written ideas as a source of

Diterbitkan oleh: 
emphasis on the interpretation and analysis of the meaning of the concept of thought in the form of expression both empirical ideas and rational ideas.

Keywords: Digital Era, Hoaks, Christian Religious Education

\section{PENDAHULUAN}

Hoaks pada dasarnya sudah ada sejak dulu dan terus berkembang hingga saat ini di era digital terus berkembang dengan begitu cepat sesuai perkembangan zaman dan teknologi. Hoaks sudah ada sejak zaman Adam dan Hawa, karena hoaks manusia jatuh ke dalam dosa dan manusia kehilangan kemuliaan Allah. Artinya Hoaks di ciptakan oleh manusia, disebarkan oleh manusia dan menghancurkan manusia itu sendiri. Semakin berkembang zaman dan semakin berkembang teknologi hoaks pun semakin berkembang dan meningkat. Oleh sebab itu, manusia harus selalu waspada dengan hoaks karena hoaks bisa menghancurkan manusia dan bahkan bisa membunuh tubuh dan jiwa manusia. Hoaks atau berita palsu ibarat virus yang terus berkembang, menyebar dan menyerang kehidupan manusia.

Penyebaran informasi/berita bohong (hoaks) saat ini makin berkembang di indonesia dan tidak dapat dipungkiri bahwa masyrakat setiap hari selalu menerima hoaks. Saluran yang paling banyak digunakan dalam penyebaran hoaks adalah media sosial. Fenomena hoaks di Indonesia saat ini menimbulkan keraguan terhadap masyarakat untuk menerima informasi karena informasi yang diterima sangat meragukan. Hal ini dimanfaatkan olah pihak-pihak yang tidak bertanggung jawab untuk menanamkan fitnah dan kebencian melalui penyebaran berita palsu atau hoaks. Menurut Christiany Juditha hoaks merupakan informasi atau berita yang berisi hal-hal yang belum pasti atau yang benar-benar bukan merupakan fakta yang terjadi (Juditha, 2018). Hoaks juga merupakan informasi yang direkayasa untuk menutupi informasi nyata, dengan kata lain hukum diartikan sebagai upaya mendistorsi fakta dengan menggunakan informasi yang meyakinkan tetapi tidak dapat diverifikasi, juga dapat diartikan sebagai tindakan mengaburkan informasi aktual, dengan membanjiri media dengan pesan yang salah sehingga dapat menutupi informasi yang benar (B. Mansyah, 2017). Hoaks atau tipuan juga merupakan bentuk Cyber crime yang tampaknya sederhana, mudah dilakukan tetapi sangat besar untuk komunitas sosial (Septanto, 2018).

Diterbitkan oleh:

Universitas Wiralodra

Jln. Ir. H. Juanda Km 3 Indramayu, Jawa Barat 
Kehadiran era digital, teknologi berkembang seiring perkembangan zaman, dengan berbagai media termasuk media online. Dalam hal ini, kemudahan dan efisiensi yang ditawarkan oleh media online dalam penggunaannya membuat media ini menjadi sarana penyebaran informasi yang sangat berpengaruh pada masyarakat. Media online tidak hanya mengubah cara informasi dikirimkan tetapi juga mengubah cara orang mengonsumsi informasi itu. Saat ini penyebaran informasi atau berita melalui media online tidak hanya dilakukan oleh situs-situs berita yang sudah dikenal oleh publik, tetapi oleh siapa saja yang merupakan pengguna internet dapat berperan dalam penyebaran informasi. Sayangnya banyak informasi atau berita yang didistribusikan secara individu atau dalam kelompok lebih banyak yang tidak dapat dipertanggungjawabkan sebagai indikasi kebenaran atau tipuan.

Menurut Yanti, Dwi Astuti mendapatkan momentum besar di era digital ini, di mana "kecepatan" menjadi yang utama, informasi menjadi mudah dibagikan tanpa melalui proses verifikasi, sehingga siapa pun, di mana saja, dan kapan saja dapat menghasilkan, mereproduksi, dan mengonsumsi hoaks konten semudah memindahkan ujung jari di gadget (Astuti, 2017). Dalam hal ini, di era digital hampir setiap orang dapat menggunakan internet di mana saja dan kapan saja sehingga orang dapat berkreasi dengan gadget mereka. Dalam penggunaan internet itu membuat semuanya serba cepat dan kurangnya pemahaman dalam penggunaan internet sehingga membuat sebagian orang menggunakan internet untuk membuat konten atau berita yang tidak benar (hoaks) kemudian menyebar melalui media sosial. Hoaks pada jaringan medis sosial di Indonesia meningkat setiap hari dengan masalah apa yang berkembang di masyarakat saat ini, pihak-pihak tertentu menggunakan situasi ini untuk memperburuk keadaan. Ini, tidak hanya untuk pembuat konten, tetapi untuk orang-orang yang menyebarkannya tanpa menyaring berita, mereka juga terlibat dalam penyebaran hoaks.

Dalam hal ini, berdasarkan laporan digital tahunan yang dirilis oleh We is Social and Hoots pada Januari 2018, pengguna Facebook masih mendominasi dua pertiga dari semua media sosial yang tersedia. Masih menurut sumber yang sama, pengguna Facebook di Indonesia mencapai 130 juta akun aktif. Ini berarti bahwa Indonesia menempati urutan keempat di dunia setelah India, Amerika, dan Brasil. Jumlah ini juga mencatat nama

Diterbitkan oleh:

Universitas Wiralodra

Jln. Ir. H. Juanda Km 3 Indramayu, Jawa Barat 
Indonesia sebagai negara di Asia Tenggara dengan jumlah pengguna Facebook terbesar. Bekasi dan Jakarta adalah kota ketiga dan keempat dengan pengguna Facebook terbesar di dunia, setelah Bangkok dan Dhaka. Sesuai dengan fakta dan kondisi yang terjadi di Indonesia, merupakan tantangan bagi pemerintah untuk mengatur penyebaran informasi. Penyebaran berbagai jenis berita yang mencakup politik, ekonomi, dan agama dibagikan oleh netizen (pengguna media sosial). Saat ini tidak ada lagi hambatan jarak dan waktu dalam menyebarkan berita. Yang lebih berbahaya, gambar dan video jenis berita dapat diedit dengan mudah seperti aslinya (Santoso, 2018).

Penyebarluasan berita atau deposito palsu yang terus berkembang di Indonesia dan sangat bermanfaat bagi masyarakat akhirnya pemerintah mengeluarkan Undang-Undang Nomor 11 Tahun 2008 tentang Informasi dan Transaksi Elektronik (ITE) yang dianggap tidak sesuai untuk diterapkan pada saat ini mengingat perkembangan pesat teknologi informasi. Pemerintah akhirnya merevisi undang-undang pada 2016 kemarin. Ini rupanya tidak mengurangi penyebaran hoaks. Sebagai warga negara yang baik, tidak pantas bagi kita untuk menyebarkan berita palsu (Santoso, 2018). Dalam hal ini, ada dua hal yang menjadi berita utama, yaitu: pertama, berita palsu harus memiliki nilai subjek objek yang merugikan. Kedua, melanggar Pasal 28 ayat 2 UU No. 11 tahun 2008 tentang informasi dan transaksi elektronik. Pasal 28 ayat 2 berbunyi, "Setiap orang dengan sengaja dan tanpa hak untuk menyebarkan informasi yang dimaksudkan untuk menghasut kebencian atau permusuhan terhadap individu dan/atau kelompok orang tertentu berdasarkan etnis, agama, ras, dan antar kelompok (SARA)". Hal ini bertujuan untuk Mencegah penipuan yang terus beredar di media sosial dan digunakan untuk umum.

Berita bohong atau hoaks sebenarnya bukan sesuatu yang baru karena berita bohong atau hoaks sudah ada sejak zaman perjanjian lama pada zaman Adam dan Hawa. Alkitab memberi tahu kita bahwa karena manusia jatuh ke dalam dosa dan manusia kehilangan kemuliaan Allah sebagai makhluk yang diciptakan menurut gambar dan rupanya Allah atau makhluk paling sempurna dari ciptaan lain. Dalam hal ini, ketika manusia jatuh dalam dosa karena godaan iblis, manusia memiliki kecenderungan untuk melakukan hal-hal sesuai dengan keinginan pribadi walaupun itu bertentangan dengan firman Allah. Ini berarti bahwa manusia terus menciptakan hoaks, menyebarkan hoaks dan mengembangkan 
hoaks sesuai dengan perkembangan zaman. Dengan demikian, dampak hoaks pada manusia adalah membunuh tubuh dan jiwa manusia itu sendiri. Dalam Alkitab kita dapat menemukan contoh-contoh berita bohong atau hoaks yang dibuat dan menyebar pada saat itu.

Dalam Perjanjian Lama diceritakan tentang nabi-nabi palsu, misalnya nabi Hananya (Yer. 28: 1-17). Dalam cerita ini, ada perselisihan antara nabi Hananya dan nabi Yeremia, di mana nabi Hananya memberikan nubuat 'gembira' yang menentang pesan nabi Yeremia tentang bencana. Dalam hal ini, nabi Hananya menjadi nabi palsu yang meramalkan kekalahan Babel dan kembalinya harta dan harta bait suci dalam waktu dua tahun. Nabi Yeremia menanggapi dengan 'Amin'. Ini berarti bahwa ia juga menginginkan kembalinya para tawanan; Namun, ia menubuatkan bencana lebih lanjut bagi orang-orang Yehuda. Lain kali buktikan bahwa Hananah adalah nabi palsu. Ketika para nabi bernubuat, tidak ada tanda yang membedakan nabi-nabi palsu dari nabi-nabi otentik. Seorang nabi sejati, nubuatnya akan muncul, sementara seorang nabi palsu menubuatkan pesan palsu (Ul. 18: 21-22).

Dalam Perjanjian Baru, kita dapat menemukannya di zaman Yesus, di mana Yesus dianggap sebagai "penipu" oleh orang-orang Farisi (Mat. 27: 62-66). Ini sangat bertentangan dengan kenyataan bahwa segala sesuatu yang dikatakan oleh Yesus selalu dipenuhi. Dalam hal ini, yang diceritakan ketika para imam dan orang Farisi datang ke Pilatus untuk menjaga pintu kubur Yesus, mereka takut para murid akan mencuri mayat Yesus, karena Yesus berkata bahwa Ia akan bangkit pada hari ketiga. Bahkan, orang-orang Farisi sangat khawatir tentang apa yang sebenarnya dikatakan oleh Yesus. Karena itu mereka berusaha menghalangi kebangkitan Yesus dengan berbagai berita palsu.

Berita bohong atau hoaks telah ada sejak manusia pertama dan manusia terus menciptakan hoaks, menyebar, dan berkembang sesuai perkembangan zaman, sehingga di era digital saat ini hoaks berkembang begitu cepat melalui media sosial. Oleh karena itu, tujuan dari penulisan ini adalah untuk memberikan pemahaman tentang bagaimana mengantisipasi hambatan yang terjadi dan yang akan terjadi melalui pengajaran pendidikan agama Kristen di lingkungan keluarga, gereja dan sekolah. Dalam hal ini, keluarga, gereja dan sekolah harus mengetahui dan menyadari tugas dan tanggung jawab mereka melalui 
peran masing-masing untuk membantu pemerintah dalam memutus mata rantai hoaks melalui pengajaran pendidikan agama Kristen di lingkungan keluarga, gereja dan sekolah setiap hari.

\section{METODE PENELITIAN}

Penelitian ini adalah studi literatur. Ini berarti bahwa penelitian ini mengacu pada data atau bahan tertulis yang berkaitan dengan topik diskusi yang diangkat, tentu saja penelitian ini menggunakan ide-ide tertulis sebagai sumber penekanan pada interpretasi dan analisis makna konsep pemikiran dalam bentuk ekspresi dari kedua empiris ide dan ide rasional. Sumber data dalam penelitian ini adalah kontak langsung dengan gagasan pendidikan agama Kristen dan radikalisme agama. Selain itu, penulis merujuk pada buku-buku lain yang membahas wacana pendidikan berbasis keterbukaan untuk memfasilitasi pemahaman.

\section{HASIL KAJIAN DAN PEMBAHASAN}

\section{Era digital}

Perkembangan teknologi kini menjadikan segala sesuatu digital dan berkembang lebih pesat. Di era digital ini, manusia pada umumnya memiliki gaya hidup baru yang tidak dapat dipisahkan dari semua perangkat elektronik. Dalam hal ini, teknologi menjadi alat yang mampu membantu sebagian besar kebutuhan dan juga memudahkan manusia untuk melakukan tugas dan pekerjaan dalam kehidupan sehari-hari mereka. Peran penting teknologi adalah apa yang membawa peradaban manusia ke era digital (Bowrey, 2005). Kehadiran era digital ditandai dengan munculnya jaringan internet, dalam teknologi informasi komputer sebagai media baru dan memiliki karakteristik jaringan atau internet. Era digital membuat media massa beralih ke media baru atau internet karena ada pergeseran budaya dalam penyampaian informasi. Dengan demikian, kemampuan media zaman digital memudahkan publik untuk menerima informasi lebih cepat. Media internet membuat media massa berbondong-bondong membungkuk (Isnaini, 2009). Kecanggihan teknologi digital membuat perbedaan besar bagi dunia di mana lahirnya berbagai jenis teknologi digital yang semakin maju telah muncul dan berbagai kelompok telah difasilitasi

Diterbitkan oleh:

Universitas Wiralodra

Jln. Ir. H. Juanda Km 3 Indramayu, Jawa Barat 
dalam mengakses informasi melalui banyak cara, dan dapat menikmati fasilitas teknologi digital secara bebas dan terkendali.

\section{Dampak positif dan negatif era digital}

Kehadiran era digitl telah membawa perubahan besar bagi kehidupan manusia, baik perubahan positif maupun negatif. Ini adalah tantangan dan peluang bagi kehidupan manusia di era digital saat ini. Dalam hal ini, tantangan di era digital telah merambah ke berbagai bidang seperti politik, ekonomi, budaya sosial, pertahanan, keamanan, dan teknologi informasi itu sendiri. Perkembangan teknologi digital tentu banyak dampak yang dirasakan di era digital ini, baik dampak positif maupun negatif. Dampak positif dari era digital antara lain (Setiawan, 2017). Perkembangan teknologi di era digital memiliki dampak positif pada kehidupan manusia. Ada beberapa hal yang berdampak positif pada manusia di era digital, yaitu: (a) informasi yang dibutuhkan dapat lebih cepat dan lebih mudah diakses. (b) pertumbuhan inovasi di berbagai bidang yang berorientasi pada teknologi digital yang memfasilitasi proses dalam pekerjaan kami (c) munculnya media massa berbasis digital, terutama media elektronik sebagai sumber pengetahuan dan informasi publik (d) meningkatkan kualitas sumber daya manusia melalui pengembangan dan pemanfaatan teknologi informasi dan komunikasi (e) munculnya berbagai sumber belajar seperti perpustakaan online, media pembelajaran online, diskusi online yang dapat meningkatkan kualitas pendidikan (f) munculnya e-bisnis seperti toko online yang menyediakan berbagai kebutuhan dan membuatnya mudah untuk mendapatkannya.

Dalam perkembangan teknologi di era digital yang membawa dampak positif pada manusia juga memiliki dampak yang negatif. Ada beberapa hal yang merupakan dampak negatif bagi manusia di era digital yanga harus diantisapasi dan dicari solusinya untuk mengindari kerugian atau bahaya, antara lain: (a) ancaman pelanggaran Hak Kekayaan Intelektual (HKI) karena akses data yang mudah dan menyebabkan orang plagiatis akan melakukan kecurangan (b) ancaman terjadinya pikiran pintas dimana anak-anak seperti terlatih untuk berpikir pendek dan kurang konsentrasi (c) ancaman penyalahgunaan pengetahuan untuk melakukan tindak pidana seperti menerobos sistem perbankan, dan lain-lain (menurunnya moralitas) (e) tidak mengefektifkan teknologi informasi sebagai media atau sarana belajar, misalnya seperti selain men-download e-book, tetapi juga

Diterbitkan oleh: 
mencetaknya, tidak hanya mengunjungi perpustakaan digital, tetapi juga masih mengunjungi gedung perpustakaan, dan lain-lain.

\section{Hoaks}

Hoaks pada dasarnya adalah berita, informasi, berita palsu atau kebohongan. Hoak diciptakan oleh manusia, disebarkan oleh manusia dan dikembangkan oleh manusia sesuai perkembangan zaman. Berita bohong atau hoaks disamakan dengan virus yang terus menyebar dalam kehidupan manusia sehingga sekarang virus hoax tersebar luas di media sosial. Di Indonesia, simpai telah menjadi wabah yang terus menyebar dengan cepat dan merajalela ke mana-mana hingga orang-orang khawatir. Berita bohong dalam hal bahasa berarti tidak cocok dengan kebenaran dan berita bohong berarti hasil akhir dari berita yang dibuat melalui proses pengeditan berita (Abede, 2005). Dalam undang-undang ITE dijelaskan bahwa berita palsu bertujuan untuk menipu, menghasut kebencian atau permusuhan dari individu dan/ atau kelompok orang tertentu berdasarkan etnis, agama, ras, dan antar kelompok (SARA), (Undang-Undang, 2018). Penipuan penyiaran adalah puncak dari pemalsuan berita dan hanya orang-orang yang tidak menggunakan akal sehat memiliki keberanian untuk menyiarkan penipuan sehingga penipuan penyiaran akan lebih berbahaya bagi opini publik jika disampaikan atau dikutip oleh media (Abede, 2005).

Hoaks telah muncul sejak abad ke-7, pada saat itu istilah hoaks digunakan dalam bidang kritik seni yang dikenal sebagai "satire hoaks art" tetapi seiring berjalannya waktu, satire hoaks art berubah menjadi satirical hoaks dan kemudian dipisahkan menjadi sindiran dan hoak. Hoaks in the Oxford Dictionary (2017) diartikan sebagai bentuk penipuan yang berniat menciptakan kekacauan (Juditha, 2018).

Hoaks dalam Kamus Besar Bahasa Indonesia berarti berita palsu, desas-desus, informasi salah, atau berita palsu. Menurut kamus bahasa Inggris, hoaks berarti olok-olok, kebohongan dan tipuan atau hoaks. Hoaks pada umumnya dibuat dengan tujuan mengolokolok dan memenangkan individu atau kelompok. Dalam hal ini, simpai didistribusikan untuk materi yang disetujui atau ditolak untuk bersenang-senang, melewati kampanye (kampanye hitam), promosi melalui debat, menciptakan dan memimpin opini publik negatif seperti fitnah, kritik tajam, penyebaran kebencian, dan lainnya. Hoaks sengaja dibuat untuk mengundang banyak orang dengan memanipulasi data dan mengingat fakta.

Diterbitkan oleh: 
Kisah-kisah menarik juga memicu karena dalam kebohongan ini telah dibuat menjadi berita palsu serta kenyataan (Fibrianti, 2018). Dengan demikian, untuk membedakan berita bohong atau hoaks dari berita lain, maka ada beberapa karakteristik yang dapat digunakan sebagai cara mengidentifikasi berita berita atau hoaks, yaitu: (a) sumber berita berasal dari sumber yang tidak dapat dipercaya, jadi tidak ada tautan ke sumber resmi (b) isi berita tidak dapat dipertanggungjawabkan kebenarannya (d) gambar, foto atau video adalah hasil rekayasa atau pengeditan (e) mengandung kalimat provokatif, sehingga mudah untuk mempengaruhi pembaca (f) biasanya mengandung unsur politik dan SARA (Fibrianti, 2018).

Kehadiran era digital di dunia berita online, terutama jejaring sosial terkenal dengan "hoaks" -nya karena di era modernis ini banyak orang yang tidak mau kalah dalam bermain gadget dan aplikasi di dalamnya. Seiring dengan perkembangan zaman, banyak aplikasi obrolan dan membaca juga muncul yang menampilkan berita dan cerita di sisi lain dunia sampai sekarang media digital atau sering disebut sebagai media sosial bermunculan dari waktu ke waktu. Era digital atau era kemajuan dari media sosial dapat dikatakan telah dimulai pada tahun 2001 dan berlanjut hingga saat ini. Kemajuan dunia digital telah menyebabkan munculnya media sosial yang telah menarik perhatian masyarakat umum dari kelas menengah ke bawah. Media sosial ini termasuk Wikipedia, Friendster, Facebook, Youtube, Twitter, Tumblr, WhatsApp, Instagram, SnapChat, Pheed, dan banyak media sosial lainnya (Syaifullah, 2008).

Media sosial atau dalam hal ini media yang didasarkan pada aplikasi percakapan instan (WhatsApp, Facebook, Instagram, dan media lainnya), juga merupakan arena untuk distribusi hoak. Hoaks adalah upaya untuk menipu atau menipu pembaca / pendengar untuk mempercayai sesuatu, meskipun pencipta berita palsu tahu bahwa berita itu palsu. Hoaks juga merupakan tipuan yang digunakan untuk mempercayai sesuatu yang salah dan seringkali tidak masuk akal melalui media online. Hoaks bertujuan untuk menciptakan opini publik, menggerakkan opini publik, membentuk persepsi serta menyenangkan yang menguji kecerdasan dan akurasi pengguna internet dan media sosial. Dalam hal ini, tujuan menyebarkan tipuan bervariasi, tetapi secara umum hoaks disebarkan sebagai lelucon atau iseng-iseng, menjatuhkan pesaing (kampanye hitam), promosi dengan penipuan, atau

Diterbitkan oleh:

Universitas Wiralodra

Jln. Ir. H. Juanda Km 3 Indramayu, Jawa Barat 
undangan untuk melakukan praktik baik yang sebenarnya tidak memiliki argumen jelas di dalamnya. Namun, ini menyebabkan banyak penerima hoaks segera menyebar ke rekanrekan mereka sehingga akhirnya hoaks cepat menyebar (Rahadi, 2017).

Dalam hal ini, jika penyebar hoaks memiliki sedikit pengetahuan dalam menggunakan internet untuk menemukan informasi yang lebih dalam atau hanya untuk memeriksa dan memeriksa kembali fakta-fakta. Ada beberapa jenis informasi yang perlu dipertimbangkan dan diperhatikan, yaitu: (a) berita palsu, berita mengarahkan berita yang berasal dari sumber aslinya (b) menghubungkan jebakan, menghubungkan yang ditempatkan strategis di dalam suatu situs dengan tujuan untuk menarik orang masuk ke situs lain (c) bias konfirmasi, menggerakkan untuk menginterpretasikan kasus yang baru d) informasi yang salah atau tidak akurat, sebagian besar yang ditanyakan tentang (e) tulisan yang menggunakan humor, ironi, hal yang dibesar-besarkan untuk mengkomentari kejadian yang sedang hangat (f) pasca-kebenaran, kejadian di mana yang lebih banyak diperbanyak fakta untuk menyusun opini publik (g) aktivitas menyebar luaskan informasi, fakta, argumen, gosip, setengah-kebenaran, atau bahkan kebohongan untuk mempengaruhi opini publik.

\section{Pandangan Alkitab terhadap hoaks}

Berita bohong atau hoaks sebenarnya bukan sesuatu yang baru karena sudah ada sejak zaman Adam dan Hawa yang berarti bahwa berita bohong telah ada sejak zaman Perjanjian Lama. Dalam hal ini, manusia menciptakan hoaks, manusia yang menyebar dan berkembang dari waktu ke waktu sesuai dengan perkembangan zaman. Dampak dari menciptakan, menyebarkan, dan mengembangkan lingkaran adalah membuat orang jatuh dalam dosa dan setiap hari selalu hidup dalam dosa. Ketika manusia jatuh dalam dosa karena godaan Iblis, manusia memiliki kecenderungan untuk melakukan hal-hal sesuai dengan keinginan pribadi walaupun itu bertentangan dengan firman Allah. Dengan potensi hoaks yang sudah ada pada manusia, terus manusia membuat hoak, menyebarkan hoak hingga sekarang. Dalam Alkitab kita dapat menemukan contoh-contoh pesan palsu atau hoaks yang dibuat dan disebarkan pada waktu itu.

Dalam Perjanjian Lama diceritakan tentang nabi-nabi palsu, misalnya nabi Hananya (Yer. 28: 1-17). Dalam cerita ini, ada perselisihan antara nabi Hananya dan nabi Yeremia,

Diterbitkan oleh:

Universitas Wiralodra

Jln. Ir. H. Juanda Km 3 Indramayu, Jawa Barat 
di mana nabi Hananya memberikan nubuat 'gembira' yang menentang pesan nabi Yeremia tentang bencana. Dalam hal ini, nabi Hananya menjadi nabi palsu yang meramalkan kekalahan Babel dan kembalinya orang buangan dan harta bait suci dalam waktu dua tahun. Nabi Yeremia menanggapi dengan 'Amin'. Ini berarti bahwa ia juga menginginkan kembalinya para tawanan; Namun, ia menubuatkan bencana lebih lanjut bagi orang-orang Yehuda. Lain kali buktikan bahwa Hananah adalah nabi palsu. Ketika para nabi bernubuat, tidak ada tanda yang membedakan nabi-nabi palsu dari nabi-nabi otentik. Seorang nabi sejati, nubuatnya akan muncul, sementara seorang nabi palsu menubuatkan pesan palsu (U1. 18: 21-22).

Dalam Perjanjian Baru, kita dapat jumpai di zaman Yesus, di mana Yesus dianggap sebagai "penyesat" oleh orang-orang Farisi (Mat. 27: 62-66). Ini sangat bertentangan dengan kenyataan yang diberikan oleh Yesus yang selalu menyangkal. Dalam hal ini, yang dikompilasi oleh para imam dan orang Farisi kepada Pilatus untuk disetujui oleh pintu kuburan Yesus, mereka takut para murid akan menyelamatkan tubuh Allah, karena Yesus berkata bahwa Ia akan bangkit pada hari ketiga. Bahkan, orang-orang Farisi sangat khawatir tentang apa yang sebenarnya diminta oleh Yesus. Karena itu adalah lawan yang menentang Yesus dengan berbagai berita palsu.

Dalam hal ini, di dalam Alkitab hoaks memiliki sinonim dengan kebohongan atau berdusta yang dilarang oleh Allah kepada umat-Nya untuk tidak menyebarkan hoaks yang telah lama dikenal oleh umat manusia. Larangan itu tercantum dalam Alkitab, Keluaran 20:16 yang ditulis sebagai "jangan mengucapkan saksi dusta tentang sesamamu." Dampak manusia menyebarkan hoaks adalah dosa. Tindakan manusia secara individu atau kolektif yang menyimpang dari kehendak dan hukum Allah. Tindakan-tindakan ini menimbulkan keadaan berdosa. Dengan demikian dampak hoaks dari sudut pandang Alkitab adalah dosa dan orang berdosa tidak dapat menyelamatkan diri dari kuasa dosa (Rizky Karo Karo: 2018).

\section{Pendidikan agama Kristen agama Kristen yang antipati terhadap hoaks di era digital Pendidikan agama Kristen antpatif hoaks di keluarga}

Keluarga adalah tempat pertama dan terpenting untuk pendidikan agama Kristen. Dalam keluarga, orang tua bertindak sebagai guru, pendidik, dan pendamping bagi anak- 
anak. Dalam hal ini, anak-anak memiliki moral dan spiritualitas yang baik tergantung pada peran orang tua dalam keluarga. Peran orang tua dalam keluarga untuk mengantisipasi hoaks adalah tindakan yang sangat tepat untuk mencegah anak-anak dalam menyebarkan berita bohong atau hoaks melalui media sosial. Keluarga Kristen adalah hadiah yang tak ternilai dari Tuhan. Keluarga Kristen, yang memainkan peran penting dalam Pendidikan Agama Kristen, bahkan lebih penting daripada jalan lain yang biasa digunakan oleh gereja untuk Pendidikan Agama Kristen. Dalam hal ini bukan berarti pendidikan yang diajarkan oleh gereja tidak penting, tetapi yang dimaksud di sini adalah pendidikan yang diajarkan gereja adalah bagian dari pendidikan yang harus diajarkan dalam keluarga. Karena jika dilihat dari ukuran waktu pendidikan yang lebih efektif adalah pendidikan dalam keluarga dibandingkan dengan pendidikan di gereja, pendidikan keluarga memiliki lebih banyak waktu daripada pendidikan yang dilakukan di gereja (Gulo, 2017).

Pendidikan agama dimulai dari keluarga dan anak-anak harus dididik dan didorong untuk menerapkan semua nilai yang diajarkan oleh firman Tuhan, dan dijauhkan dari segala sesuatu yang dilarang oleh firman Tuhan. Dalam hal ini, berita bohong adalah sesuatu yang dilarang oleh Tuhan dan menyebarkan kebohongan seperti berbohong kepada orang lain. Itu berarti menciptakan dan menyebarkan hoaks adalah sesuatu yang melanggar perintah dan larangan Tuhan. Larangan berbohong ditulis dalam Sepuluh Perintah "Jangan bersaksi dusta tentang sesamamu (Keluaran 20:16). Tuhan secara konsisten dan tegas membenci bahasa dusta (Amsal 6:17). Semua pembohong akan mendapat bagian dalam danau api dan belerang (Wahyu 21: 8 Jadi, Alkitab menekankan keseriusan konsekuensi rohani sebagai hasil dari bermain dengan ketidakbenaran.

Oleh karena itu, orang tua memiliki peran yang sangat penting dalam keluarga untuk menagantisipasi hoaks di era digital sehingga anak tidak menjadi pencipta dan penyebar hoaks melalui media sosial. Peran yang harus orang tua lakukan pada anak untuk mengantisipasi hoaks yaitu: (a) orang tua berperan sebagai pengarjar, sebagai pengajar orang tua menjelaskan pada anak bahwa membuat berita hoaks atau memyebarkan berita hoaks merupakan hal yang tidak benar dihadapan Allah dan melanggar perinta dan larangan Allah (b) orang tua berperan sebagai pendidik, sebagai pendidik orang tua harus mendidik anak dalam penggunaan media sosial untuk sebelum menyebarkan berita yang

Diterbitkan oleh:

Universitas Wiralodra

Jln. Ir. H. Juanda Km 3 Indramayu, Jawa Barat 
tersebar di media sosial harus mengecek dari mana sumber berita untuk memastikan kebenaran berita tersebut (c) orang tua berperan sebagai mentor, orang tua sebagai mentor harus mengontrol dan mendapingi anak adalam penggunaan media sosial dalam memposting berita berupa teks atau gambar di media sosial yang digunkan oleh anak misalnya media sosial Wikipedia, Friendster, Facebook,Youtube, Twitter, Tumblr, WhatsApp, Instagram, SnapChat, Pheed, dan banyak media sosial lainnya. (d) orang tua menjadi teladan, orang tua yang berperan sebagai pengajar, pendidik, pendampingan bagi anak dalam mengantisipasi hoaks maka orang tua juga harus menjadi teladan dalam keluarga. Dalam hal ini, keteladanan orang tua merupakan media pembelajaran yang di munculkan kepada anak sehingga akan terekam dalam diri anak. Artinya jika orang tua munculkan hoaks maka anak juga akan mencermin hoaks dalam dirinya karena apa yang tercermin dari orang tua itulah yang akan tercermin dalam diri anak.

\section{Pendidikan agama Kristen antipatif hoaks di gereja}

Peran pendidikan agama Kristen yang dilakukan digereja untuk mengantisipasi hoaks pada era digital merupakan hal yang sangat penting. Dalam hal ini, gereja yang berperan sebagai pembentuk iman jemaat, gereja juga harus berperan dalam pembentukan moral yang dimana gereja harus dengan tegas menyatakan bahwa membuat berita bohong dan menyebarkan berita bohong adalah hal yang berbohong kepada diri sendiri, kepada sesame dan juga kepada Allah. Hal itu akan sangat merusak moral dan spiritual sehingga terjerumus ke dalam dosa dan Allah sangat menentang hal itu karena berbuat dusta. Oleh sebab itu, gereja harus debngan tegas melarang jemaat agar tidak menyebarkan berita hoaks tetapi menyebarkan berita-berita yang benar.

Dalam hal ini, sebagai orang Kristen harus belajar untuk selalu berpikir kritis dan tidak mudah percaya pada sesuatu yang pada pandangan pertama dipandang sebagai "kebenaran". Pembuat "hoaks" bukanlah orang bodoh. Pesan "hoaks" dibuat dengan teori dan pendekatan psikologis yang bahkan dapat mencapai pikiran bawah sadar manusia untuk mencapai tujuan mereka secara efektif. Ini bukan hanya karya "orang iseng". Dalam berita "hoaks" sangat sering ditemukan unsur-unsur yang faktual dan benar. Mereka pandai mengumpulkan fakta dengan hal-hal palsu yang mereka tempel dengan sangat hati-hati. Ingat peringatan Yesus: "Lalu tuan itu memuji bendahara yang tidak jujur, karena dia telah

Diterbitkan oleh: 
bertindak dengan cerdik. Karena anak-anak di dunia ini lebih licik daripada tetangga mereka daripada anak-anak terang" (Kel 16:18).

\section{Pendidikan agama Kristen amtipatif hoaks di sekolah}

Peran pendidikan agama Kristen di sekolah merupakan hal yang sangat penting dan tepat untuk mengantisipasi hoak di sekolah. Dalam hal ini, yang bertanggung jawab untuk mengantisipasi adalah guru karena guru sebagai garda terdepan yang bisa melindungi dan memerangi dari siswa-siswa. Peran guru pendidikan agama Kristen sangat dibutuhkan untuk mengantisipasi hoaks pada siswa-siswa di media sosial. Guru mempunyai hak untuk mendidik, membimbing, serta mengarahkan siswa-siswi dalam penggunaan media sosial. Guru pendidikan agama Kristen adalah pribadi yang bertanggung jawab untuk mengajar, membimbing, dan mengarahkan siswa-siswa dalam penggunaan media sosial sehingga mereka tidak menyebarkan hoaks melalui media sosial. Guru pendidikan agama Kristen harus memahami bahwa pendidikan agama Kristen di sekolah tidak hanya sebatas memberikan memberikan ilmu kepada siswa-siswa, tetapi juga harus mengarahkan mereka dalam penggunaan media sosial sehingga mereka tidak penyebar berita bohong atau hoaks (Ermindyawati, 2019). Guru pendidikan agama Kristen memiliki Peran untuk mengantisipasi berita hoaks terhadap siswa mutlak dibutuhkan. Oleh karena itu, dalam pembelajaran pendidikan agama krusten guru harus mampu menyelipkan himbauan tentang bahaya berita hoaks. Selain itu, penanaman pendidikan agama Kristen pada siswa juga harus diperkuat. Dengan demikian, untuk mengantisipasi hoaks di sekolah, ada beberapa cara yang bisa digunakan, yaitu: (a) mengajar siswa untuk mengidentifikasi berita yang termasuk hoaks atau tidak (b) mengajak para siswa untuk tidak begitu saja percaya pada berita hoaks. Selain itu, mengajak siswa mencari referensi lain dari situs online dan membandingkan isinya dari berita ia terima sebelum di sebarkan.

\section{KESIMPULAN}

Sesuai dengan pembahasan tentang pendidikan agama Kristen yang antipatif terhadap hoaks di era digital maka dapat disimpulkan bahwa untuk menantisipasi hoaks yang terus menyebar seperti virus yang terus merajalelah dalam kehidupan masyarakat di indonesia maka membutuhkan pendidikan agama Kristen antipatif dalam keluarga, gereja

Diterbitkan oleh:

Universitas Wiralodra

Jln. Ir. H. Juanda Km 3 Indramayu, Jawa Barat 
dan sekolah. Dalam hal ini, pendidikan antipatif yang harus di lakukan di rumah untuk mengantisipasi hoaks di era digital melalui peran orang tua dalam keluarga. Peran yang perlu orang tua lakukan dalam keluarga ialah orang tua berperan sebagai pengajar, sebagai pendidik, sebagai mentor dan menjadi teladan. Pendidikan agama Kristen yang antipatif di gereja untuk mengantisipasi hoaks di era digital, gereja berperan untuk mengajarkan kepada jemaat bahwa menciptakan dan menyebarkan berita hoaks adalah melakukan saksi dusta yang dilarang oleh Allah dalam Alkitab. Pendidikan agama Kristen yang antipatif untuk mengatisipasi hoaks di era digital, perlu peran dari guru pendidikan agam Kristen di sekolah untuk mengajarkan kepada siswa sehingga tidak menciptakan den menyebarkan hoaks. Selain itu, untuk mengatasi hoaks, perlu menanamkan pemahaman pendidikan agama yang kuat kepada masyrakat di lingkungan keluarga, gereja dan gereja atau tempat beribada. Selain itu juga perlu peran dari kelurga, sekolah untuk mengantisipasi pemyebran hoaks di dalam kehidupan sehari-hari. Dengan adanya tindakan mengantisipasi hoaks di lingkungan keluarga, gereja dan sekolah setiap hari maka akan sangat membantu pemerintah untuk memutuskan mata rantai hoaks yang sedang berkembang di indonesia saat.

\section{DAFTAR PUSTAKA}

Alkitab, Perjanjian Lama dan Perjanjian Baru.

B. Mansyah. (2017). Fenomena Berita Hoax Media Sosial (Facebook) Dalam Menghadapi Pemilihan Umum Gubernur DKI Jakarta Tahun. Fakultas Ilmu Sosial dan Ilmu

Juditha, C. (2018). Interaksi Komunikasi Hoax di Media Sosial serta Antisipasinya,. Jurnal Pekommas, 3(1), 31-44.

Ermindyawati, L. (2019). Peranan Guru Pendidikan Agama Kristen Terhadap Perilaku Siswa-Siswi Di SD Negeri 01 Ujung Watu Jepara. FIDEI: Jurnal Teologi Sistematika Dan Praktika, 2(1), 40-61. https://doi.org/10.34081/fidei.v2i1.27

Gulo, S. (2017). Prinsip pendidikan agama Kristen dalam keluaga bagi keluarga Banua Niha Keriso Protestan (BNKP) Gunungsitoli. 1(3), 456.

Septanto, H. (2018). Pengaruh HOAX dan Ujaran Kebencian Sebuah Cyber Crime Dengan Teknologi Sederhana di Kehidupan Sosial Masyarakat. Sain Dan Teknologi, 5(2),

Diterbitkan oleh: 
187.

Bowrey, K. (2005). Law and Internet Cultures. Melbourne: Cambridge University Press.

Santoso, L.W. (2018). Berita Hoax dalam Zaman Alkitab sampai Kekinian. Surabaya: Universitas Kristen Petra.

Abede, P.M. (2005). Manajemen Berita antara Idealisme dan Realita. Surabaya: Papirus.

Rahadi, D. R. (2017). Perilaku Pengguna Dan Informasi Hoax Di Media Sosial, (Junal Manejemen kewirausahaan,. 5(1), 61.

Fibrianti, R. (2018). Makalah Pengaruh Berita Bohong (Hoax) Melalui Media Sosial Terhadap Sila Ketiga Pancasila "Persatuan Indonesia”, . Jakarta.

Karo, R.K. (2018). Analisis Hubungan Antara Dosa dan Penyebaran Berita Bohong (Hoax) Ditinjau Berdasarkan Perspektif Hukum Pidana Indonesia. Tangerang: Universitas Pelita Harapan.

Setiawan, W. (2017). Era Digital dan Tantangannya. Seminar Nasional Pendidikan 2017, 1-9. Retrieved from https://core.ac.uk/download/pdf/87779963.pdf

Syaifullah, I. (2008). Fenomena Hoax Di Media Sosial Dalam Pandangan Hermeneutika, ( Surabaya. Surabaya: Univesitas Islam Negri Sunan Ampel Surabaya.

Undang-Undang. (2018). nomor 19 tahun 2016 tentang perubahan atas undang-undang nomor 28 tahun 2008 tentang informasi dan transaksi elektronik. Jakarta.

Astuti, Y.D. (2017). Peperangan Generasi Digital Natives Melawan Digital Hoax Melalui Kompetisi Kreatif,. Informasi Kajian Ilmu Komunikasi, 47(2), 232.

Isnaini, Y. (2009). Hak Cipta Dan Tantangannya Di Era Cyber Space,. Jakarta: Ghalia Indonesia. 